\title{
TUL - SATAVUOTIAS, JOKA KARKASI IKKUNASTA MUTTA EI KADONNUT
}

\author{
Seppo Hentilä \\ professori emeritus, Helsingin yliopisto
}

Artikkeli perustuu kirjoittajan laatimaan, toukokuussa 2019 julkistettuun TUL:n satavuotishistoriaan "TUL liikuttaa, kasvattaa, vaikuttaa - Suomen Työväen Urheiluliitto 1919-2019." SKS, Helsinki. 405 s.

Työväen Urheiluliitto TUL (vuodesta 1991 Suomen Työväen Urheiluliitto) vietti satavuotisjuhlaansa kuluvan vuoden tammikuun 26. päivänä. Kun kansalaisjärjestö täyttää Suomessa sata vuotta, on aihetta kysellä pitkäikäisyyden perään. TUL:n kohdalla kysymys on sitäkin perustellumpi, sillä maassamme ei liene toista kansalaisjärjestöä, jota sen vastustajat ja kilpailijat olisivat yhtä innokkaasti koettaneet saattaa pois päiviltä. Siitä ovat osoituksena ne kolmisenkymmentä urheilun valtakunnanliittohanketta, joilla Suomen Voimistelu- ja Urheiluliitto SVUL (vuodesta 1961 Suomen Valtakunnan Urheiluliitto) yritti nielaista TUL:n ja poimia rusinat pullasta. Nämä yritykset loppuivat vuonna 1993, kun SVUL itse lakkasi olemasta jouduttuaan talousvaikeuksiensa takia lopettamaan toimintansa. Mutta senkin jälkeen, kun tulee puhe urheilun ja liikunnan järjestörakenteesta, nousee tietyillä tahoilla esiin kysymys TUL:n tarpeellisuudesta ja olemassaolon oikeutuksesta.

\section{Sisällissota repi Suomen rikki}

Yhteiskuntaluokkien välinen kuilu oli Suomessa vuoden 1918 jälkeen syvempi ja ristiriidat katkerampia kuin ennen sisällissotaa. Vastakohtaa on monesti konkretisoitu näkymällä maa- laisidyllistä, jossa lähes jokaisen maalaiskylän peltoaukean laidoilla seisoi valkoinen suojeluskuntatalo ja punainen työväentalo. Peltoaukea oli vastakkaisten ideologisten maailmojen raja, jonka ylittäminen oli henkisesti hyvin vaikeaa. Ken rohkeni sen tehdä, joutui omiensa hylkäämäksi tai vähintään yhteisönsä sylkykupiksi.

Valkoisen Suomen jyrkimmän porvariston kostotoimien tavoitteena oli työväestön omaehtoisen järjestötoiminnan täydellinen tukahduttaminen. Siihen nähden on hämmästyttävää, miten nopeasti työväenliike nousi jaloilleen. Vallankumousyrityksestä sivussa pysytelleet maltilliset sosialidemokraatit elvyttivät SDP:n, ja lisäksi vuonna 1919 perustettiin useita uusia valtakunnallisia työväenjärjestöjä. Niistä merkittävimmät olivat kuluvana vuonna sadan vuoden ikään ehtineet Työväen Urheiluliitto TUL ja Työväen Sivistysliitto TSL. Valkoisessa Suomessa työväenliike linnoittautui järjestöjensä suojiin.

SDP menestyi odottamattoman hyvin sekä joulukuun 1918 kunnallisvaaleissa että maaliskuun 1919 eduskuntavaaleissa. Näin siitäkin huolimatta, että sosialidemokraatit olivat menettäneet sisällissodan seurauksena vähintään 50 000-60 000 potentiaalista äänestäjäänsä. Noin 27000 punaista oli saanut surmansa kaa- 
tuneina ja valkoisen terrorin uhreina tai nääntynyt vankileireillä nälkään ja kulkutauteihin; Neuvosto-Venäjälle oli paennut kymmenisen tuhatta punaista, ja lisäksi kymmenet tuhannet olivat menettäneet kansalaisluottamuksensa eivätkä saaneet äänestää. Silti SDP sai 80 paikkaa ja palasi eduskuntaan suurimmaksi puolueeksi. Sillä oli vain 12 edustajaa vähemmän kuin lokakuun 1917 vaalien jälkeen.

\section{Ympärysvaltojen voitto pelasti Suomen demokratian}

Miten työväenliikkeen nopea elpyminen oli Suomen kaltaisessa "valkoisen hämärän maassa" mahdollista? Kuten sanottu, jyrkin laitaoikeisto halusi kitkeä työväenliikkeen järjestötoiminnan maasta juuriaan myöten. Ilman toimintaan halukasta ja pystyvää järjestöväkeä ei uusi alku olisi tietenkään onnistunut. Mahdollisuudet olisivat olleet vieläkin vähäisemmät, jos kaikkein kostonhimoisimmat valkoiset olisivat päässeet viemään "vapaussotansa" loppuun. Heidän taholtaan Suomen demokratiaa uhkasi kaiken aikaa oikeistodiktatuuri, jonka varjo väistyi lopullisesti vasta 1930-luvulla.

Suomen kuningashanke kaatui ympärysvaltojen voittoon marraskuussa 1918 , ja maamme säästyi joutumasta Saksan protektoraatiksi. Svinhufvudin ja Paasikiven johtama, joulukuussa 1918 kansalliseksi kokoomuspuolueeksi järjestäytynyt monarkistinen laitaoikeisto joutui joksikin aikaa sivuun, kun voittajavallat edellyttivät, että Suomen oli irtisanouduttava saksalaissuuntauksesta ja järjestettävä vapaat eduskuntavaalit. Vasta niiden jälkeen, toukokuussa 1919, Iso-Britannia ja Yhdysvallat tunnustivat Suomen itsenäisyyden. Hallitusvalta siirtyi Suomessa edistysmieliselle porvaristolle, ja ensimmäiseksi tasavallan presidentiksi voitiin valita edistyspuolueen K. J. Ståhlberg, joka luonnehti poliittista linjaansa kolmella käsitteellä: laillisuus, edistys ja kansanvalta.

Maailmansodan lopputulos takasi sen, että parlamentaarinen demokratia säilyi, ja Suomesta tuli 17. heinäkuuta 1919 vahvistetun hallitusmuodon nojalla se tasavalta, joka meil- lä vielä nykyäänkin on. Poliittisen järjestelmän osalta murros oli keväällä ja kesällä 1919 itse asiassa paljon syvempi kuin syksyllä 1944, jolloin vanha eliitti sai johtaa Suomen sodasta rauhaan. Meiltä pakkaa helposti unohtumaan se, että Suomen työväenliikkeen nopea elpyminen tuli mahdolliseksi maailmansodan lopputuloksen aiheuttamassa uudessa poliittisessa suhdanteessa. Suomessa johtavaan rooliin noussut edistysmielinen porvaristo, jota edustivat maalaisliitto, edistyspuolue ja ruotsinkielinen vasemmisto, oli valmis yhteistyöhön sosialidemokraattien kanssa.

\section{TUL:n perustaminen oli työläisurheiluväen vastaus valkoisen Suomen kostotoimille}

Valkoisen Suomen kostotoimet kohdistuivat rajuimmin niihin, jotka olivat ottaneen osaa sisällissotaan punaisella puolella. Jyrkimmät valkoiset hyväksyivät yhdistyksiinsä vain porvarillisiin arvoihin sitoutuneen ja sosialismista vapaan "valkoisen työmiehen". Sellaisia ei kuitenkaan Suomenmaasta kovin paljoa löytynyt, vaikka työnantajapiirit perustivat eräässä vaiheessa heitä varten jopa oman ammattijärjestön (Vapaa Työväenliitto) ja urheilujärjestön (Vapaa Työväen Urheiluliitto).

Alistumisen sijaan työväestö alkoi perustaa välittömästi sisällissodan päättymisen jälkeen omia poliittisia, ammatillisia, urheilu-, sivistysja kulttuurijärjestöjä. Kuten edellä on sanottu, tämä tuli nopeasti mahdolliseksi edistysmielisen porvariston hallitsemassa poliittisessa suhdanteessa. Kohta oli Suomessa kaikkea kaksi. Osuustoiminnan pohjalta syntyivät vähitellen myös työväen liikelaitokset. Ja kun työväenliike hajosi vuonna 1918 Suomen Kommunistisen Puolueen (SKP) perustamisen myötä kahtia, syntyi vielä uusi jakoperuste.

Urheiluliikkeessä porvariston ja työväestön yhteistoiminta oli ollut ennen sisällissotaa laajempaa kuin missään muussa kansanliikkeessä. Suurin osa hieman yli kahdesta sadasta työväenyhdistysten alaisesta urheiluseurasta kuului Suomen Voimistelu- ja Urheiluliittoon 
(SVUL). Monet työväenseurat olivat sekä jäsenmääränsä että urheilumenestyksensä ansiosta maan johtavia seuroja. Lippulaiva oli Helsingin Työväenyhdistyksen HTY:n alainen Helsingin Jyry. Sisällissodassa taisteli jyryläisistä koottu komppania, ja punakaarteihin kuului muutoinkin tuhansia työläisurheilijoita.

Marraskuun lopulla 1918 SVUL päätti erottaa jäsenyydestään ne seurat, jotka olivat taistelleet sisällissodassa osastoina punaisella puolella, sekä ne seurat, joiden jäsenistä puolet tai enemmän oli tuomittu valtiorikosoikeudessa kapinaan osallistumisesta. Ajan hengen mukaisesti päätöstä perusteltiin sillä, että urheiluelämä oli vapautettava uhasta joutua "isänmaalle vihamielisten ainesten tyyssijaksi". SVUL:n johdon tarkoituksena oli tukahduttaa työläisurheilu Suomesta ikiajoiksi. Sen sijaan kapinasta sivussa pysytelleiden työläisurheilijoiden, jotka olivat valmiita sopeutumaan valkoisen Suomen urheilun porvarillisiin arvoihin, toivottiin jatkavan toimintaansa SVUL:n seuroissa.

Tammikuun 26. päivänä 1919 kokoontuivat 56 erotetun työläisurheiluseuran valtuuttamat edustajat Helsinkiin raittiusyhdistys Koiton talolle perustamaan Työväen Urheiluliittoa. Päivälleen vuotta aikaisemmin Helsingin työväentalon torniin oli nostettu punainen lyhty vallankumouksen alkamisen merkiksi. TUL:n perustavan kokouksen pitämistä vallankumouksen alkamisen vuosipäivänä ei ollut suunniteltu. Se oli puhdas sattuma, mikä johtui siitä, että tammikuun 26. päivä oli sunnuntai.

TUL:n perustaminen oli valkoisen Suomen urheilujohtajille isku vasten kasvoja. SVUL:n johto ei suin surminkaan osannut odottaa, että kapinalliset jo pari kuukautta erottamispäätöksen jälkeen perustaisivat oman urheiluliiton. Pahinta oli se, että kapinallisten liitto kykeni rekrytoimaan joukkoonsa tuhansia sellaisia urheilijoita, jotka olisivat kelvanneet vahvistamaan SVUL:nkin rivejä. Tässä on tultu Suomen urheilun järjestöhistorian ikuisuuskysymyksen äärelle: porvarillinen urheiluliike piti TUL:n olemassaoloa alusta lähtien Suomen urheilun hajottamisena ja heikentämisenä.

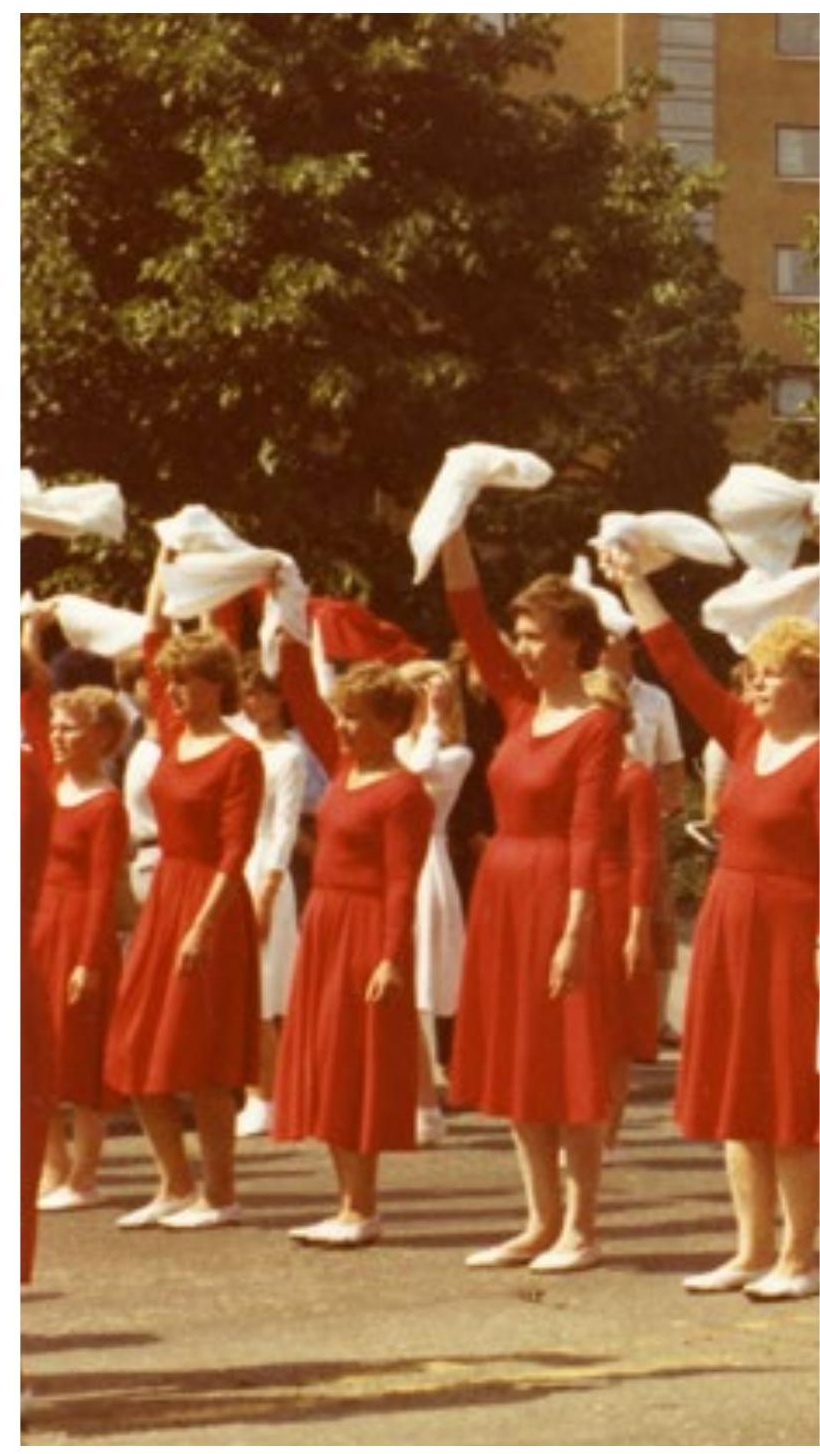

TUL:n 75-vuotisjuhlat Tampereella elokuussa 1984. Kuvassa kenttäohjelmaan osallistuvia esiintymisasuissaan marssimassa Ratinan stadionille. Kuvaaja Pauli Kukkala. Kuva:Työväenmuseo Werstas.

Monet ehkä muistavat ruotsalaisen Jonas Jonassonin riemukkaan veijariromaanin satavuotiaasta Allan Karlssonista, joka karkasi syntymäpäivänään vanhainkodin ikkunasta ja katosi huimiin seikkailuihin. TUL sen sijaan karkasi jo syntymäpäivänään valkoisen Suomen urheilujohtajilta, mutta se ei kadonnut, vaan ryhtyi järjestämään työläisurheiluväelle urheilutoimintaa.

TUL kieltäytyi itsepintaisesti 1920- ja 1930-luvuilla kaikesta yhteistoiminnasta porvarillisen urheilun kanssa. Tärkein syy siihen 


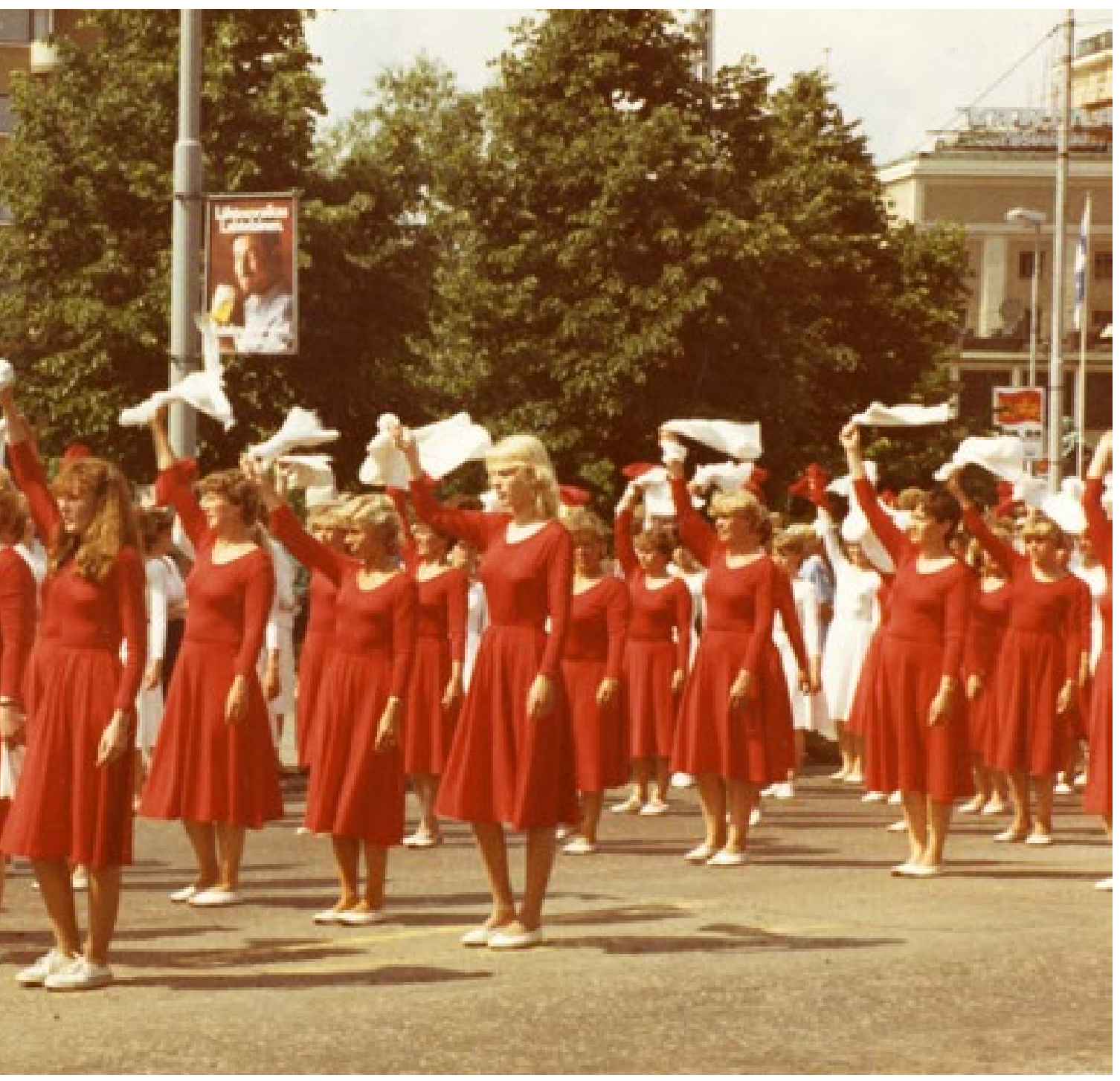

oli valkoisessa Suomessa vallinnut työväenliikkeelle vihamielinen ilmapiiri. TUL ei halunnut olla missään tekemisissä sortajiensa kanssa. Se ei sallinut jäsentensä edustavan Suomea kansainvälisissä arvokisoissa vaan luotti siihen, että kansainvälisen työväen urheiluliikkeen "punainen olympia" olisi Suomen työläisurheilijoille terveempi kilpailuympäristö kuin "porvarillinen olympia”.

\section{Suurten joukkojen urheiluttaja ja liikuttaja}

TUL julistautui alusta lähtien suurten joukkojen liikuttajaksi, mutta on syytä täsmentää, mitä sillä aikanaan tarkoitettiin. Suurten joukkojen liikuttaminen ei tarkoittanut, toisin kuin voisi kuvitella, kuntoliikuntaa, koska sellaista ei vielä ennen 1960-lukua tunnettu. Liikunta ei ollut edes käsitteenä vielä yleisesti käytössä, vaan puhuttiin yleisesti urheilusta ja voimistelusta erillisinä toimintoina. Urheilu tarkoitti amatöörikilpaurheilua, eikä muuta urheilua ollutkaan. Kilpaurheilua harrastivat periaatteessa kaikki seuran jäsenet ikänsä ja kuntonsa mukaan. Voimistelu eli kilpaurheilun rinnalla, mutta se oli joukkovoimistelua, eikä siinä kilpailtu.

Toinen väärinkäsitys, johon 1920- ja 1930-lukujen työväenkulttuurista puhuttaessa usein törmää, koskee joukkoliikkeen laajuutta. TUL:n jäsenmäärä kasvoi 1930-luvun alkuun mennessä noin 30 000:een. Talvisodan syttyessä liitossa oli vajaat 50000 jäsentä. Mikään 
valtaisa joukkoliike TUL ei siis ollut. Sen toiminta tavoitti maan kaksimiljoonaisesta palkkatyöväestöstä vain murto-osan. Silti TUL oli jäsenmäärältään maan suurin työväenjärjestö, sillä sekä SDP:n että SAK:n jäsenmäärät jäivät vielä 1930-luvulla selvästi pienemmiksi kuin TUL:n. Samaan aikaan kahdessa maan suurimmassa järjestössä, suojeluskuntajärjestössä ja Lotta Svärdissä, oli jäseniä yhteensä kymmenen kertaa enemmän kuin TUL:ssä. SVUL:nkin jäsenmäärä oli kaksi kertaa suurempi kuin TUL:n. Luvut kuvastavat suomalaisen kansalaisyhteiskunnan tilaa ja poliittisia voimasuhteita maailmansotien välisenä aikana. TUL, kuten koko muu työväenliike, oli sisällissodan jälkeisessä valkoisessa Suomessa kaiken aikaa ahtaalla. Varsinkin lapuanliikkeen harjoittaman terrorin hurjimpina vuosina 1929-1932 työväenjärjestöihin liittyminen tarkoitti vaaraa joutua syrjinnän, pilkan, painostuksen ja jopa väkivallan kohteeksi.

Vuonna 1930 voimaan tulleiden niin sanottujen kommunistilakien nojalla kiellettiin 157 työväen urheiluseuraa ja piirijärjestöä. Peräti puolet TUL:n silloisesta jäsenkunnasta, noin 14000 urheilijaa, joutui liiton ulkopuolelle. Heistä osa liittyi pian sellaisiin seuroihin, jotka saivat jatkaa toimintaansa. Kun yleinen ilmapiiri oli työväenliikettä kohtaan vihamielinen, on selvää, etteivät läheskään kaikki uskaltaneet liittyä TUL:oon. Sivuun jättäytyneiden määrää on mahdotonta arvioida, mutta jonkinlaista osviittaa antanee se, että liiton jäsenmäärä nelinkertaistui yhdessä humauksessa pian jatkosodan päättymisen jälkeen.

\section{TUL:n suuri nousu sotien jälkeen}

Työväen Urheiluliitto kilpaili 1940-luvun lopulla SVUL:n kanssa tasaväkisesti Suomen suurimman urheilujärjestön asemasta. Kummankin jäsenmäärä oli noin neljännesmiljoona. 1940-luvun toisella puoliskolla TUL:n seurojen määrä kolminkertaistui 300:sta 900:aan. Liiton seuraverkosto kasvoi koko maassa, niin kaupungeissa kuin maaseudullakin. Enää ei ollut suojeluskuntia eikä valkoisen Suomen ääri- oikean laidan järjestöjä, jotka olisivat ahdistelleet työväenliikettä.

Suurten joukkojen urheiluttamisessa TUL:n uusi aluevaltaus oli jatkosodan jälkeen Itä- ja Pohjois-Suomen maaseutu. Työväen urheiluseuroja perustettiin pienimpiä syrjäkyliä myöten satamäärin. 1940- ja 1950-luvuilla TUL:n kehitystä hidastivat liiton sisäiset poliittiset riidat ja hajaannus. Suurten joukkojen liikuttajana SVUL meni jo 1960-luvulla menojaan. Silti TUL:nkin jäsenmäärä kasvoi, mutta on huomattava, että tuon ajan jäsentilastoihin ei ole luottamista, koska niitä peukaloitiin sekä suuremman valtionavun toivossa että liiton sisäisiä voimainmittelöitä varten.

Kun puhutaan todella suurten joukkojen liikuttamisesta, on aloitettava vasta 1960-luvusta. Tuolloin alkoivat hurjasti kasvaneen kuntoliikunnan markkinoista kilpailla monet eri tahot. Vaikka TUL julisti olevansa suurten joukkojen liikuttaja, se ei oikein tahtonut saada otetta modernista kuntoliikunnasta. Yhteistyöltä ayliikkeen kanssa odotettiin paljon, koska työläisurheilun eheytyminen oli nostattanut uskoa joukkoliikkeen mahdollisuuksiin. TUL:n ja ayväen yhteistyöstä ei kuitenkaan tullut odotetun kaltaista menestystarinaa. Työpaikkaliikunnassakaan TUL ei kyennyt valloittamaan johtoasemaa koko maan mittakaavassa.

Työväen Urheiluliiton kasvu järjestönä huipentui vuonna 1979 toteutuneeseen työläisurheilun eheytymiseen. Liiton seurojen määrä nousi 1 500:aan, eli seuroja tuli 300 lisää, ja kun jäsenmäärä kasvoi 200 000:1la, se lähestyi puolta miljoonaa. Tuolloin TUL oli suurten joukkojen liikuttajana suurimmillaan. 1980-luvulla asemat vielä säilyivät, mutta 1990-luvulta 2010-luvulle liitto menetti sekä jäsenkunnastaan että seuroistaan noin puolet. Satavuotisjuhlien aikoihin oltiin suunnilleen samoissa luvuissa kuin 50 vuotta sitten.

Kun Suomen Liikunta ja Urheilu (SLU) perustettiin koordinoimaan urheilun ja liikunnan järjestökenttää vuonna 1993, TUL:lle tarjoutui tilaisuus nousta avainasemaan kuntoliikunnan kehittäjänä. Liitto teki ahkerasti valistustyötä 
kuntoliikunnan puolesta ja järjesti näyttäviä kampanjoita, mutta kaikkein suurimpia joukkoja se ei tavoittanut. Liikuntakäyttäytymistä koskevat tutkimukset osoittivat vääjäämättä, että suurin osa kansalaisista ei tarvinnut liikkumiseensa minkään valtakunnan järjestöjä eikä seuroja. Joukot liikuttivat itse itseään.

TUL:n osuus kuntoliikunnan markkinoista on nykyään jo selvästi pienempi kuin vaikkapa yksityisten liikuntayritysten. Työyhteisöliikunnan perustan mullisti liikuntaseteleiden käyttöönotto 1990-luvulla. Ihmiset saattoivat valita vapaasti harrastamisensa paikan ja ajan. Tämä soveltui hyvin ajan henkeen. Yksilölähtöiset käyttäytymismallit poikkesivat perinteisen kansalaistoiminnan malleista. Tämä on varmasti yksi tärkeimmistä syistä siihen, miksi TUL:n jäsenmäärä on viimeksi kuluneiden 20 vuoden aikana vähentynyt niin voimakkaasti.

\section{TUL on ollut ennen kaikkea nuorison kasvattaja}

Kasvatus on ollut kautta aikojen TUL:n periaateohjelmien avainsana. Se oli myös ensimmäisiä sanoja, joilla liitto määritteli toimintansa tarkoituksen vuonna 1919. Kasvatus ei ole rajoittunut pelkkään urheilu- ja liikuntakasvatukseen, vaan se on aina sisältänyt arvokasvatusta ja yhteiskunnallista valistusta.

TUL omaksui 1920- ja 1930-luvuilla KeskiEuroopan maiden sosialidemokraattisessa työväenliikkeessä vallalla olleen marxilaisen kasvatusideologian. Sen merkittävin kehittäjä oli itävaltalainen Max Adler. Häneltä saatujen vaikutteiden mukaisesti TUL pyrki kasvattamaan jäsenistään henkisesti ja fyysisesti tasapainoisia "uusia ihmisiä". Vaikka tavoite oli kovin ihanteellinen, se ei tarkoittanut vain palopuheita tai sosialistista aivopesua vaan myös normaalia seuratoimintaa, jossa urheilun ohella harrastettiin monia henkisen kulttuurin muotoja.

Sosialistiselta urheiluinternationaalilta lainattu, nykyihmisen korvaan kovin mahtipontiselta kuulostava lause, "Emme kasvata ruumista emmekä sielua, vaan ihmistä", kertoo TUL:n kasvatustavoitteista kaiken oleellisen. Liitto ha- lusi kasvattaa jäseniään siten, että henkinen ja fyysinen kasvu tukisivat toisiaan. Siten voitaisiin torjua urheiluun pesiytyneitä lieveilmiöitä, kuten liiallista ennätysten ja palkintojen tavoittelua, ammattilaisuutta, sankarinpalvontaa ja kiihkonationalismia.

TUL:lle tarjoutui vuoden 1993 SLU-ratkaisun myötä ainutlaatuinen tilaisuus profiloitua nuorisotoiminnan kehittäjäksi. Liiton valmiudet menestyä nuorisotoiminnassa olivat selvästi paremmat kuin sen valmiudet menestyä kuntoliikunnassa. Tämä johtui siitä, että lähes kaikki TUL:n seurat suhtautuivat periaatteessa myönteisesti siihen, että nuorisotoiminta nostettiin painopisteeksi. Suhtautuminen kuntoliikuntaan oli sen sijaan toisenlaista. Kuntoliikuntaa kohtaan esiintyi myös paljon ristiriitaisia tuntoja kilpaurheiluun suuntautuneissa seuroissa.

TUL käytti nuorisotyöhön 1990-luvulta lähtien huomattavan suuren osan niukentuneista resursseistaan. Millään muulla järjestön toimialalla ei myöskään syntynyt yhtä merkittäviä innovaatioita. Kun arvioidaan liiton vaikutusta nuorison kasvattajana, vuonna 1990 käynnistynyt LETE-nuorisoprojekti oli vertaansa vailla. Lyhenne tulee sanoista liikuntaa, elämyksiä, tietoa ja taitoa sekä empatiaa. LETE:n tuottama kasvatusaineisto oli erittäin korkeatasoista ja monipuolista, olivathan sen tekijöinä oman alansa parhaat asiantuntijat. Innovaatioista hienoimpia oli teorian eli LETE-oppaiden ja -kortistojen vieminen käyttöön seurojen harjoituksiin, urheilukouluihin ja nuorisoleireille.

TUL:n nuorisokasvatuksen tavaramerkeistä toinen, 2000-luvulla käynnistyneet Joy Games -tapahtumat, onnistui yhdistämään hienolla tavalla liiton yhteisöllisyyttä ja modernia nuorisokulttuuria. Uusien lajien ja liikunnan muotojen ottaminen ennakkoluulottomasti tapahtumien ohjelmaan oli oikea keino nuorison kiinnostuksen herättämiseksi.

TUL on ollut jäsenmäärällä ja toiminnallisella aktiivisuudella mitattuna perustamisestaan lähtien Suomen työväenliikkeen suurin nuorisojärjestö. Työväen poliittiset nuorisojärjestöt eivät ole parhaimmillaankaan yltäneet sa- 
maan. Liiton tarjoama nuorisokasvatus ei ehkä enää 2000-luvulla tavoittanut yhtä laajoja joukkoja kuin 1970- tai 1980-luvuilla, mutta se oli kuitenkin korkealaatuista. Se tarjosi erittäin hyviä elämän eväitä niille tuhansille nuorille, jotka halusivat harrastaa liikuntaa TUL:n seuroissa.

\section{TUL:n panos Suomen kilpa- ja huippu-urheilussa}

Kilpa- ja huippu-urheilussa menestyminen oli työväen urheiluseurojen arvoasteikossa jo ennen liiton perustamista erittäin korkealla. Työläisurheilijat olivat parhaimmillaan aivan samoissa lajeissa kuin muutkin suomalaiset huiput. Vahvimpia lajeja olivat paini, yleisurheilu ja hiihto. TUL:n urheilijat edustivat 1920- ja 1930-luvuilla maataan kolmissa Sosialistisen urheiluinternationaalin työläisolympialaisten kesä- ja talvikisoissa. He kilpailivat siniristilippu edustusasunsa rintamuksessa ja katsoivat edustavansa maataan yhtä hyvin ja yhtä arvokkaasti kuin porvarilliset kilpailijansa KOK:n olympiakisoissa.

TUL:n urheilijat olivat työläisolympialaisissa ylivoimaisia kaikissa niissä lajeissa, joihin he osallistuivat. Tämä johtui siitä, että huippuurheilua ei TUL:n veljesjärjestöissä arvostettu samalla tavalla kuin Suomessa, ja siksi kilpailujen taso oli työläisolympialaisissa useimmissa lajeissa heikompi kuin KOK:n olympiakisoissa. Vaikka TUL:n urheilijoiden ylivoimaisuutta ihailtiin erityisesti työläisurheilun suurmaassa Saksassa, kriittisimmät tarkkailijat ihmettelivät sitä, olivatko suomalaiset lainkaan oikeita työläisurheilijoita. Hehän syyllistyivät aivan samaan kuin porvarilliset urheilijat: ylenmääräiseen harjoitteluun sekä ennätysten ja palkintojen metsästämiseen.

Kolmikymmenluvulla kymmeniä TUL:n huippu-urheilijoita siirtyi edustamaan porvarillisia seuroja. Taloudellisten houkuttimien lisäksi loikkausten syynä olivat järjestön sisäinen hajaannus ja kommunistilait. Hajaannuksen ja seurojen lakkautusten vuoksi liiton ulkopuolelle joutuneet urheilijat joutuivat etsimään itselleen uutta urheilullista kotia.
Suomen edustusurheilu vahvistui 1930-luvun alussa merkittävästi Työväen Urheiluliitosta loikanneiden huippujen ansiosta. TUL:n kahdessa vahvimmassa lajissa, painissa ja nyrkkeilyssä, tulokkaat voittivat 1930-luvulla jopa 40 prosenttia kaikista SM-mitaleista. Kymmenet TUL:n kasvatit edustivat Suomea Los Angelesin olympiakisoissa vuonna 1932 ja Berliinin kisoissa neljää vuotta myöhemmin.

Toisen maailmansodan jälkeen TUL:n liikuntapoliittiset vaikutusmahdollisuudet laajenivat huomattavasti, kun yhteistyö SVUL:n, sen lajiliittojen ja Suomen Olympiakomitean kanssa käynnistyi. TUL:n urheilijat pääsivät ensi kertaa osallistumaan SM-tason kilpailutoimintaan ja maan edustusurheiluun. Liikuntapolitiikkaa hallitsivat kuitenkin jatkuvat järjestöriidat ja valtakunnanliittoväännöt.

Sotien jälkeen Työväen Urheiluliitto tuli täysipainoisesti mukaan Suomen edustusurheiluun. Maamme kansainvälinen urheilumenestys ei kuitenkaan noussut enää lähellekään 1920- ja 1930-lukujen tasoa. Tuolloinhan Suomi oli olympiamenestyksellä mitattuna yksi urheilun suurvalloista. Vuosina 1959-1962 TUL joutui keskusjärjestöjen yhteistoiminnan katkeamisen vuoksi kokonaan sivuun kansainvälisestä edustusurheilusta.

TUL:n panos Suomen huippu-urheilussa oli vahvimmillaan 1980-luvulla, jolloin koko maan taso jo laski. Liiton osuus kaikista SMmitaleista nousi 1980 -luvulla 19 prosentista 24 prosenttiin. Naisvoimistelussa, pöytätenniksessä ja pyöräilyssä TUL:n urheilijat voittivat yli puolet lajinsa kaikista SM-mitaleista.

\section{Sukupuolten tasa-arvosta monipuoliseen yhdenvertaisuuteen}

Työväenliikkeessä uskottiin pitkään, että kaikkinainen tasa-arvo toteutuu "automaattisesti" sosialistisessa yhteiskunnassa, kun luokkaerot on poistettu. Työväen Urheiluliiton naiset nostivat sukupuolten tasa-arvon vahvasti esille jo 1930-luvulla. He olivat sekä Suomessa että kansainvälisessä työläisurheiluliikkeessä edelläkävijöitä myös siinä, että he tulivat ennakko- 
luulottomasti mukaan myös kilpa- ja huippuurheiluun.

TUL on ollut Suomessa kiistatta edelläkävijä liikunnan tasa-arvoa ja yhdenvertaisuutta koskevissa ohjelmallisissa kannanotoissa. Silti on muistettava, että vasta 2000-luvulla naiset saavuttivat tasa-arvoisen aseman liiton johtoelinten kokoonpanossa. 2010-luvulla nousi vahvasti esiin laaja-alainen tasa-arvonäkemys, johon kuuluvat taloudellinen, sukupuolten välinen ja alueellinen sekä eri vähemmistöjen tasa-arvo. Liitto on murtanut sukupuolisten vähemmistöjen ja maahanmuuttajien liikuntaan kohdistuvia ennakkoluuloja määrätietoisemmin kuin mikään muu liikuntajärjestö Suomessa. Erityisen tärkeitä ovat olleet TUL:n kannanotot sen puolesta, että liikunnan eriarvoistuminen saataisiin pysäytetyksi ja kaikilla lapsilla ja nuorilla olisi vanhempien varallisuudesta riippumatta mahdollisuudet harjoittaa liikuntaa tasa-arvoisesti.

Suomen urheilun suurin ongelma ei ole huippu-urheilun kilpailukyvyn heikentyminen, vaikka sitä jatkuvasti päivitellään. Paljon suurempi ongelma on eriarvoistuminen, joka näkyy siinä, että vähävaraisten perheiden lasten on mahdotonta päästä harrastamaan tiettyjä lajeja, koska niiden vuosikustannukset saattavat olla tuhansia euroja. Jos arvokisamitaleista puhutaan, niitä menetetään jo "etukäteen" siksi, että suuri osa lahjakkaista nuorista putoaa pois sen takia, että heidän vanhemmillaan ei ole varaa kalliin harrastuksen kustantamiseen.

\section{TUL:n pitkän iän salaisuuksia}

Miksi Työväen Urheiluliitto on yhtenä harvoista perinteisistä kansalaisjärjestöistä yltänyt sadan vuoden ikään? Syitä on tietysti monia ja erilaisia, eikä tässä ole tarpeen ryhtyä laatimaan niistä pitkiä luetteloita. Ylivoimaisesti tärkein on joka tapauksessa työväestön luokka-asemaan perustunut yhteisöllisyys ja sen pohjalle rakentunut tietoisuus kuulumisesta tähän yhteisöön. Niin kauan kuin omaehtoinen työväenkulttuuri erottautui Suomessa omaksi erilliskulttuurikseen, työväen yhteisöllisyyttä ei tarvinnut erik- seen järjestää. Se kuului luonnostaan paikallisten työväenyhteisöjen elämäntapaan. Näissä yhteisöissä TUL:n seuratoimintaan tulleet lapset ja nuoret kasvoivat, sosiaalistuivat ja aikuistuivat. Työväen urheiluseura oli monipuolinen elämän koulu, jossa opittiin paljon muutakin kuin urheilua ja voimistelua. Järjestödemokratian sääntöihin perustunut kansalaistoiminta kasvatti nuoria yhteistyöhön, toisten kunnioittamiseen ja yhteiskunnalliseen osallistumiseen.

Niin sanotun ensimmäisen tasavallan Suomessa kansalaisyhteiskunta oli jakautunut kahteen poliittisesti vastakkaiseen erilliskulttuuriin. Valtaosa urheilusta kiinnostuneista työläisnuorista oli liittynyt kuin luonnostaan, "luokkansa kutsumana”, TUL:n seuroihin. Vuoden 1918 sisällissodan varjot olivat tällä kohdalla todella pitkät.

Vaikka kansalaisjärjestöt ryhmittyivät vielä viime sotien jälkeenkin tietyiksi poliittisiksi klustereiksi, kulttuurinen leirijako alkoi jo selvästi rakoilla. Urheilujärjestöissä se tarkoitti käytännössä sitä, ettei urheiluseuraan liittyminen enää määräytynyt yksinomaan sosiaalisen taustan tai poliittisen katsomuksen perusteella. Seuroihin alettiin liittyä yhä useammin harrastettava laji edellä. Aluksi liikennettä oli enemmän siihen suuntaan, että työläistaustaisia nuoria hakeutui porvarillisiin seuroihin, mutta 1960-luvulta lähtien alkoi vähitellen näkyä siirtymistä myös päinvastaiseen suuntaan. Myös porvarillisesta ja keskiluokkaisesta taustasta oli tulijoita TUL:n seuroihin. Näissä luokkarajat ylittävissä siirtymissä motiivina oli liittyminen sellaiseen seuraan, joka tarjosi omalla paikkakunnalla parhaat harrastus- ja kilpailumahdollisuudet siinä lajissa, josta itse kukin oli kiinnostunut.

Kun TUL:n jäseneksi ei enää "synnytä", siihen tullaan urheilu, laji ja kaveripiiri edellä. Niistä koostuvat myös seurojen perustana olevat paikallisyhteisöt. Tietynlainen taitekohta saavutettiin 1970-luvulla, jolloin sosiologi Paavo Seppänen osoitti tutkimuksissaan, että kaikista urheiluseuroihin kuuluvista työläistaustaisia jäseniä oli SVUL:ssä enemmän kuin 


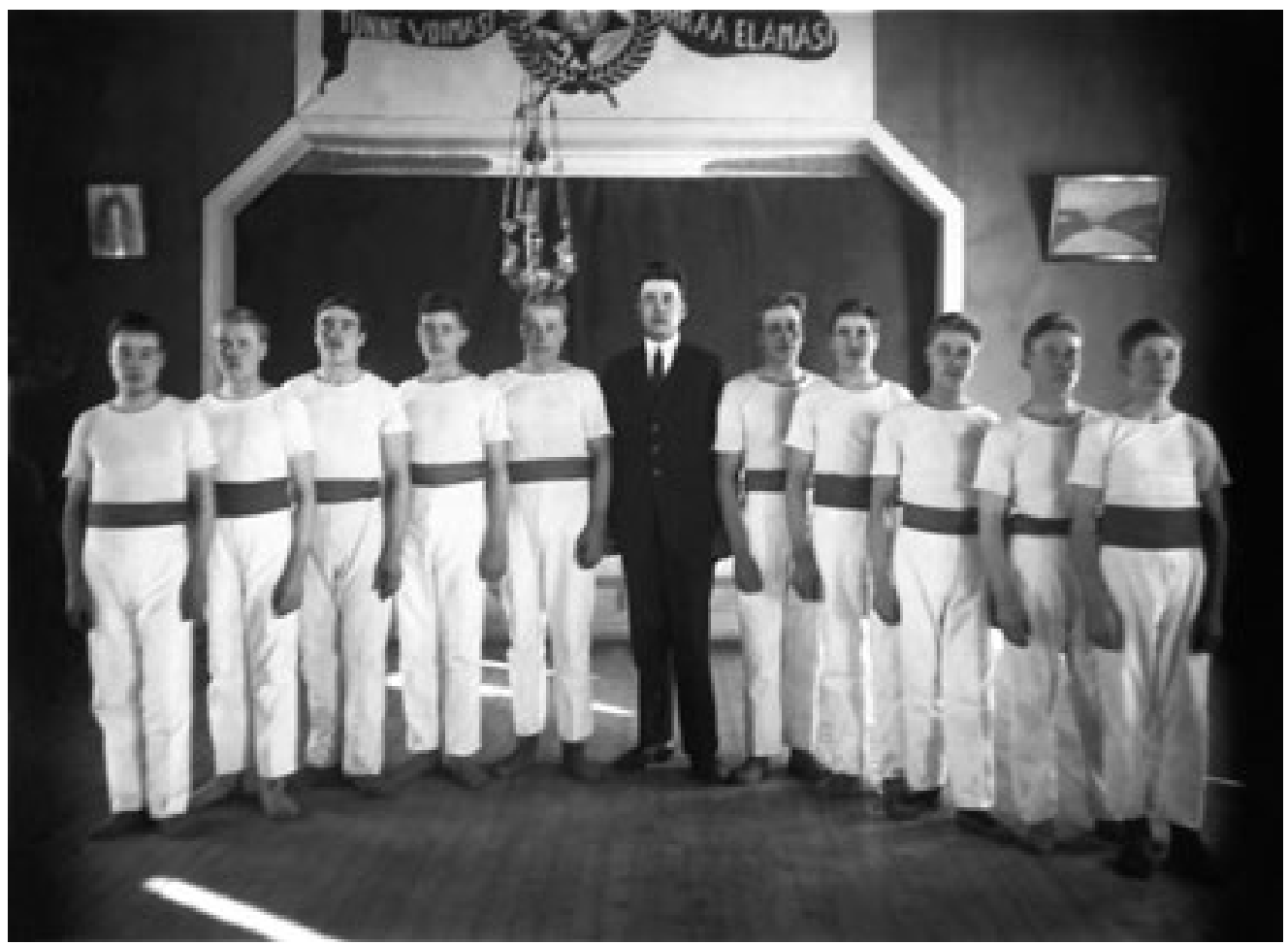

Teuvan Auran voimistelijat johtajanaan Arvo Säättö 1920-Iuvulla. Kuva: Kansan Arkisto.

TUL:ssä. Nykyään sosiaalisella taustalla tai poliittisella mielipiteellä ei ole urheiluseuran valinnassa mitään merkitystä. Työväen perinteisen yhteisöllisyyden murtuminen on joka tapauksessa se tekijä, joka on kaikkein syvällisimmin vaikuttanut TUL:n asemaan ja toimintaedellytyksiin. Kaikkein rajuimmin muutos näkyy siinä, että 1980-luvun vaihteesta, jolloin liiton jäsenmäärä lähenteli suurimmillaan jopa puolta miljoonaa, on tultu reilusti alas, hieman yli 200 000:een.

Työväen yhteisöllisyys ja toisaalta sen mureneminen ovat muokanneet Työväen Urheiluliittoa enemmän kuin mikään muu. Toinen tärkeä tekijä on ollut kilpailu porvarillisen urheilun, toisin sanoen SVUL:n, kanssa. Miekka ei tässä ollut vain kaksi- vaan moniteräinen. Yhtäältä vastakohta tarkoitti kamppailua olemassaolosta, elämästä ja kuolemasta, mutta niin kauan kuin TUL jaksoi taistella, sen omat rivit vahvistuivat. Urheilullinen kilpailuasetelma jatkui vielä sittenkin, kun TUL ja SVUL sotavuosista lähtien harjoittivat yhteistoimintaa laajalla rintamalla. SVUL:n katoaminen Suomen urheilun näyttämöltä vuonna 1993 oli tavallaan myös TUL:lle menetys, koska liittojen välistä kilpailua ei enää sen jälkeen ollut. Aikoinaan sanottiin, että viimeinen tilaisuus, jossa saattoi vielä nähdä luokkataistelua käytännössä, olivat TUL:n ja Suomen Nyrkkeilyliiton väliset liittoottelut Helsingin vanhassa Messuhallissa. 